\title{
OD ČASTÍC K POLIAM: ONTOLOGICKÉ OTÁZKY FYZIKY
}

RÓBERT MACO, Filozofická fakulta Univerzity Komenského v Bratislave, Katedra filozofie a dejín filozofie, Bratislava, SR

MACO, R.: From Particles to Fields: Ontological Issues of Physics FILOZOFIA, 75, 2020, No 6, pp. $431-445$

The question of the ultimate constituents of the physical universe was one of the first questions at the dawn of the Western tradition of philosophy. At present, the most successful answers to this question are offered by the fundamental theories of elementary particle physics, which are formulated within the broader conceptual and mathematical apparatus of quantum field theory. The aim of this paper is to explain in an accessible manner the fundamental changes brought about by the transition from particle to field understanding of the universe in contemporary physics. The brief account of Newton's ontological view of the world serves both as an introduction and as a background to what follows. The paper also intends to address and encourage philosophers interested in ontological problems to study the latest physical theories despite their mathematical complexity and apparent inaccessibility.

Keywords: Particle - Force - Field - Physics - Ontology - Quantum field theory Standard model - Newton

The streets are fields that never die.

J. Morrison

Základnou a z nášho pohl'adu najzaujímavejšou filozofickou otázkou súčasnej fyziky je otázka vzt’ahu medzi vysoko abstraktným a sofistikovaným matematickým formalizmom, ktorý je nevyhnutnou súčastou našich fundamentálnych teórií a reálnym svetom, ktorý sa tieto teórie usilujú opisovat' a vysvetl'ovat'. Túto základnú otázku možno rozdelit' na viacero čiastkových otázok:

- Aký obraz sveta nám vlastne predkladajú naše najúspešnejšie fundamentálne fyzikálne teórie?

- Máme vôbec od fundamentálnej fyziky v súčasnosti očakávat' niečo také ako obraz sveta? 
- Ktoré entity sa z pohl’adu súčasnej fyziky ukazujú ako najlepší kandidáti na základné stavebné kamene univerza?

- Kol'ko „ontologickej dôvery“ máme vkladat' do matematického aparátu fyzikálnych teórií, ktoré zaznamenávajú najväčšie úspechy z hl’adiska experimentálne potvrdených predikcií a technologického využitia?

V týchto otázkach sú obsiahnuté dve metaforické slovné spojenia: „obraz sveta“ a „základné stavebné kamene“. Pre účely tohto textu nie je naším zámerom poskytnút’ pre tieto termíny explicitnú definíciu. Namiesto toho chceme ponúknut' osvetlenie prostredníctvom exemplifikácie. Ukážeme si, aký obraz sveta a aké stavebné kamene univerza postuloval Newton, vychádzajúc zo svojich matematických princípov prírodnej filozofie, zo svojich rozsiahlych pozorovaní a experimentov, a taktiež zo svojich teologických presvedčení.

Tento postup so sebou prináša okrem väčšej názornosti aj tú výhodu, že si tým zároveň vypracujeme kontrastné pozadie $\mathrm{k}$ súčasnej fyzike, ktorá zvykne byt' najčastejšie porovnávaná s tým, čo sa označuje ako „mechanistický obraz sveta“, ktorý sa automaticky prepája s newtonovskou mechanikou. Zatial čo mechanistický obraz sveta sa vníma - alebo aspoň prezentuje - ako relatívne jednoduchý, priehl'adný, názorný (intuitívny) a commonsensical, nová (moderná) fyzika má povest' niečoho mimoriadne zložitého, abstraktného a idúceho proti ,zdravému rozumu“. Citáty o jej záhadnosti a nepochopitel'nosti sú dobre známe a na tomto mieste ich netreba opakovat'.

Ciel'om tohto článku však nie je tematizovat' všetky jednotlivé prvky súčasnej fyziky, ktoré dali podnet $\mathrm{k}$ spomenutým výrokom. Ako už bolo povedané v úvode, svoju pozornost' obmedzíme na to, čo by sme mohli stručne nazvat' „ontológiou súčasnej fundamentálnej fyziky“. Interpretačné problémy, ktoré sú najčastejšie spájané s kvantovou mechanikou a ktoré sa s ňou ako predmet ustavičných kontroverzií t'ahajú už od prvých dekád dvadsiateho storočia, sú síce takisto úzko prepojené s ontologickými otázkami, no v súvislosti so zvolenou výkladovou stratégiou a v neposlednom rade aj z priestorových dôvodov sa chceme zamerat' výlučne na spomenutý užší problém.

\section{Newtonova koncepcia}

Keby sme pri výklade Newtonovho fyzikálneho obrazu sveta chceli učinit' zadost' všetkým historickým a konceptuálnym detailom jeho myslenia, bol by to skôr námet na samostatnú knihu. Je prirodzené, že niektoré jeho názory sa postupne vyvíjali a menili, v niektorých obdobiach si „hypotézy vymýšlaal“ častejšie, inokedy menej, alebo bol aspoň opatrnejší pri ich formulovaní. Koniec koncov, významní znalci dejín vedy a Newtona ako A. R. Hall, M. B. Hall, I. B. Cohen či A. Koyré sa rozchádzajú dokonca 
aj v niektorých základných bodoch Newtonovej koncepcie (pozri napr. Hall, Hall 1962, 192 - 193). Ked’že naším primárnym zámerom nie je diskutovat' o rôznych interpretačných kontroverziách, ale skôr získat' istý ucelený, a pokial' možno názorný a zrozumitel'ný obraz, zvolíme si tú podobu Newtonovej koncepcie, ktorú predstavil vo svojej poslednej vel'kej prírodovednej práci Optika. ${ }^{1}$

Aký je teda najpravdepodobnejší obraz sveta podla zrelého Newtona? Vyjadrené s maximálnou stručnost'ou: Centrom všetkého je najvyššia inteligentná bytost' (Boh), ktorá je sama nehmotná, no je tvorcom hmotného sveta, ktorý stvorila v podobe pohyblivých častíc, ktoré svojimi rozmanitými pohybmi a vzájomným spájaním generujú celú rozmanitost' sveta, prístupnú našim zmyslom (a prípadne aj tú, ktorá je mimo dosahu našich zmyslov²). Ked’že nám ide o povahu fyzikálneho sveta, dovolíme si v d'alšom ponechat' bokom povahu nemateriálneho stvoritel'a a konkrétny spôsob jeho interakcie so svetom. Ked' už je však reč o interakciách, nesmieme zabudnút', že okrem teologickej otázky možnej interakcie nehmotnej inteligencie s hmotným svetom je tu aj problém interakcie jednotlivých častí hmotného sveta, čiže sveta spomínaných častíc. Na opis a vysvetlenie tejto dynamickej (interakčnej) stránky sveta Newton prináša do hry ešte jeden kl'účový prvok, ktorý označuje ako „silu“ (force, power, virtue). Fyzikálny svet teda nie je len hromada korpuskúl, ale je to skôr súbor korpuskúl spolu s ich vzájomnými silovými pôsobeniami.

Skôr ako si povieme viac o presnejšej povahe spomínaných častíc a spomínaného silového pôsobenia, bude dobré pripomenút' si, aké základné výzvy stáli pred Newtonom ako prírodovedcom na začiatku osemnásteho storočia. V Optike Newton okrem hlavnej témy, teda svetla, najčastejšie spomína také javy, ako sú (statická) elektrina, magnetizmus, fermentačné procesy, šŕrenie tepla a kohéziu telies. Išlo o zdanlivo jednoduché otázky, na ktoré bolo prekvapivo t'ažké odpovedat' (dokonca aj z pohladu fyziky začiatku dvadsiateho storočia): Ako je možné, že nejaký malý nerast má schopnost' zdvihnút' malé kúsky železa a prekonat' tak gravitačné pôsobenie celej zemegule? Ako je možné, že niektoré iné predmety získavajú podobnú schopnost' prit’ahovat' čisto v dôsledku predchádzajúceho trenia? Ako je vôbec možné, že zložené telesá držia pohromade?

Newton v Optike v závere svojej vedeckej kariéry priznáva, že na tieto otázky zatial' nenašiel adekvátne odpovede. Záver Optiky preto koncipoval vo forme sugestívnych (alebo rétorických) otázok (Queries), ktoré v d’alších edíciách dopĺn̆al o nové

${ }^{1}$ Prvé vydanie Newtonovej Optiky pochádza z roku 1704, no v d’alšom texte budeme vychádzat' $\mathrm{z}$ rozšíreného tretieho vydania z roku 1721.

${ }^{2}$ Newton v Optike zvažuje a pokladá za myslitel'nú aj takú možnost', že Boh stvoril na viacerých odl'ahlých miestach nekonečného priestoru častice s odlišnými charakteristikami, čo by mohlo mat' za následok existenciu odlišných prírodných zákonov v rôznych častiach univerza (Newton 1721 , 379 - 380). 
a rozširoval ich až do podoby akýchsi samostatných úvah o fundamentálnych prvkoch svojho fyzikálneho, filozofického a teologického obrazu sveta. Práve tu možno nájst' najpodrobnejšie informácie o Newtonových predstavách o povahe hmoty a jej ultimatívnych konštituentoch.

Akými vlastnost'ami sa vyznačujú newtonovské najmenšie častice (atómy) hmoty? Sú pevné, hmotné (massy), tvrdé, nepreniknutel'né, pohyblivé, majú rôzne tvary a vel'kosti a možno disponujú aj d'alšími vlastnost'ami. Pevnost' znamená schopnost' držat' svoj tvar, tvrdost' znamená schopnost' odolávat' akejkol'vek fragmentácii alebo „ošúchaniu“, nepreniknutel'nost' znamená schopnost' zabránit' akémukol'vek inému hmotnému telesu obsadit' miesto, ktoré zaberá daná častica, a nakoniec pohyblivost' znamená pre časticu schopnost' menit' miesto. Okrem spomenutých vlastností Newton pripisuje časticiam takzvanú vis inertiae, ktorej doslovný preklad by síce bol „,sila zotrvačnosti““ (prípadne „zotrvačná sila“). Jej povahu nám ovel’a lepšie ako tento preklad ozrejmí porovnanie s pasážou o pohybových zákonoch a s príslušnou definíciou z Princípov (Newton 1687, 2; 12). Vis inertiae alebo materiae vis insita (ako ju Newton nazýva v Princípoch) je schopnost' telesa (častice) vzdorovat' zmene svojho pohybového stavu. Implicitne je teda prítomná v prvom pohybovom zákone (zákone zotrvačnosti). I. B. Cohen vystopoval použivanie termínu vis insita v Newtonovom kratšom traktáte De motu (O pohybe), ktorý o niekol'ko rokov predchádzal Principia mathematica.

Z Cohenovho výkladu vyzdvihnem len dva body, ktoré sú dôležité v tomto našom kontexte (pozri Cohen 1971, 66-68). Po prvé, newtonovskú vis insita, respektíve inertiae treba (napriek mätúcim pomenovaniam) chápat' ako schopnost' (vlastnost') častice, ktorá je pre ňu inherentná (esenciálna), nie je do nej len zvonku vložená (insita). A po druhé, táto vis vlastne nie je silou, pokial' pod silou máme na mysli (ako je to bežné dnes $\mathrm{v}$ rámci klasickej mechaniky) to, čo spôsobuje zmenu pohybového stavu, teda zrýchlenie. Silu v tomto zmysle Newton tiež označuje latinským výrazom vis, ibaže s iným adjektívom - hovorí o nej ako o vis impressa (čiže doslova „vtlačená sila").

Pripomenút' tieto jemné detaily Newtonovej terminológie je dôležité preto, lebo naším ciel'om je dospiet' $\mathrm{k}$ Newtonovmu fyzikálnemu obrazu sveta, v ktorom evidentne figurujú nielen atomárne častice, ale aj sily pôsobiace medzi časticami. Je možné vytvorit' si o týchto silách podobne názornú predstavu, ako to bolo pri elementárnych časticiach? Akým druhom entity sú vlastne tieto newtonovské interakčné sily? Sú v nejakom zmysle „hmotné“ a existujúce nejakým spôsobom popri hmotných časticiach? Alebo by sme ich mali skôr chápat' ako nejaké osobité atribúty (potencie) samých častíc, čiže mali by sme ich z hl’adiska klasického rozlíšenia substancia-akcident chápat' ako nesamostatné momenty častíc? Alebo ide o čisto pojmové nástroje, 
ku ktorým by sme nemali vôbec hladat' nijaký predmetný korelát v realite? Je snaha začlenit' sily do „ontologického inventára univerza“ len nešt’astným pokusom o reifikáciu istého dobre fungujúceho matematického formalizmu?

Úplne jasnú a jednoznačnú odpoved’ na takto položené otázky u Newtona zrejme nenájdeme. Z Newtonových Queries na konci Optiky však môžeme aspoň extrahovat' isté náznaky o tom, ako o týchto veciach uvažoval. Explicitne napríklad hovorí o tom, že častice (atómy hmoty) sú pohybované určitými ,aktívnymi princípmi“ a ako konkrétne príklady uvádza gravitáciu, ale aj „to, čo zapríčiňuje fermentáciu a kohéziu telies“ (Newton 1721, 376). Samozrejme, slovné spojenie ako „aktívne princípy“ je dráždivo neurčité vo vzt’ahu $\mathrm{k}$ vyššie nastoleným otázkam. Treba si však uvedomit', že neurčitost' Newtonovej formulácie mohla byt' sčasti zámerná, pretože Newton si bol dobre vedomý horúcej pôdy, po ktorej jeho teória síl kráčala. Od publikovania Princípov bol terčom kritiky, či už zo strany stúpencov kartezianizmu, alebo zo strany takých významných myslitel'ov ako Leibniz či Huygens. Všetkým týmto bol nanajvýš podozrivý spôsob, akým sa podl'a nich Newton usiloval vysvetlit' pohyby nebeských telies postulovaním „gravitačnej sily“ pôsobiacej na dial'ku, ktorá týmto zástancom striktného mechanistického prístupu vo fyzike evokovala zdiskreditované qualitates occultae starej aristotelovsko-scholastickej metafyziky. V tret'om vydaní Optiky Newton práve v súvislosti so spomínanými ,aktívnymi princípmi“ doplnil priamu reakciu na tento typ kritiky: „Tieto princípy nepokladám za skryté [occult] kvality, ktoré majú plynút' zo špecifických foriem vecí, ale za všeobecné zákony prírody, ktorými sú veci samy utvárané. Ich pravdivost' sa nám ukazuje prostredníctvom fenoménov, hoci ich príčiny ešte nie sú objavené“ (Newton 1721, 376 - 377).

Newtonova stratégia voči spomínaným kritikom sa dá zhrnút týmto spôsobom: prítažlivé a odpudivé sily, chápané ako aktívne princípy pôsobiace v prírode, navrhuje chápat' nie ako skryté príčiny, ktoré generujú pozorovatel'né účinky, ale naopak, vychádzajúc z pozorovatel'ných tendencií vecí $\mathrm{k}$ vzájomnému približovaniu a odd’al'ovaniu sa postuluje isté aktívne princípy, chápané ako matematicky vyjadritel'né zákonitosti, ktorých príčiny zatial' nepozná, a preto si ich nechce špekulatívne domýšsl'at'. Z tohto hl'adiska teda môžu newtonovské sily figurovat' $\mathrm{v}$ ontologickom inventári sveta iba vo forme matematizovatel'ných „tendencií“ vecí. Tento záver je v dobrom súlade s Newtonovým skorším vyhlásením „Hypotheses non fingo“ v rámci Princípov. Do tej istej kategórie sa dá zaradit' aj slávna pasáž z Newtonovej korešpondencie (list Bentleymu z 1692), ktorý sa vyslovene týka nemechanistického silového pôsobenia na dial'ku, ale aj - čo je nemenej dôležité - otázky, či je gravitačná sila inherentnou súčast'ou hmoty:

„Je nemyslitel'né, aby neživá hrubá hmota (bez sprostredkovania niečoho iného, čo nie je hmotné) ovplyvňovala inú hmotu a pôsobila na ňu bez vzájomného kontaktu, 
ako by to muselo byt', keby bola gravitácia v zmysle Epikura niečím inherentným a esenciálnym v hmote. (...) Príčinou gravitácie musí byt’ nejaký agens, konštantne pôsobiaci podl'a istých zákonov, no či je tento agens hmotný alebo nehmotný, to je otázka, ktorú som ponechal na zváženie svojim čitatel’om“ (Janiak 2004, 102 - 103).

Ako teda vyzerá Newtonov ontologický obraz sveta? Ako vidno z predchádzajúcich riadkov, ani v rámci „klasickej fyziky“ nie je takýto obraz úplne jednoduchý a priamočiary. V predchádzajúcom výklade sme sa sústredili najmä na problémy, ktoré vyvstávajú pri Newtonovom chápaní síl, a na ich problematický ontologický status. Pritom sme si však ešte vždy mohli mysliet', že častice ako druhý typ fundamentálnych entít predstavujú niečo viac-menej jasné, zrozumitel'né a v určitom zmysle aj názorné. Ako však ukázal už vývoj fyzikálneho myslenia v osemnástom storočí, koncepcia tvrdých, nepreniknutel'ných atd'. častíc v sebe skrýva napriek svojej názornosti množstvo dodatočných nevyriešených otázok. Niektoré predchádzajúce problémy sa takpovediac iba presúvajú na hlbšiu úroveň: Ak je odpoved' na otázku, čo drží pohromade napríklad zrnko piesku to, že sú to nejaké prít’ǎlivé sily pôsobiace na krátke vzdialenosti medzi elementárnymi časticami, nemožno sa vyhnút' otázke, čo drží pohromade samotné častice ako rozpriestranené a prakticky neporušitel'né kúsky hmoty. V snahe riešit tieto a d’alšie otázky predložil napríklad v polovici osemnásteho storočia chorvátsky prírodovedec Rudjer J. Boškovič novú koncepciu fundamentálnych prvkov prírody, $\mathrm{v}$ ktorej originálnym spôsobom skombinoval leibnizovskú monadológiu a newtonovskú atomistiku: svet podl'a jeho videnia je na fundamentálnej fyzikálnej úrovni tvorený bodovými (bezrozmernými) silovými centrami, ktorých jedinými esenciálnymi vlastnost'ami je zotrvačnost' a schopnost' vzájomne na seba silovo pôsobit' $\mathrm{v}$ závislosti od vzdialenosti. Tento dynamický obraz sveta upútal na začiatku devätnásteho storočia na istý čas aj pozornost' M. Faradaya, ktorý v dôsledku svojich prelomových experimentálnych výskumov v oblasti magnetizmu a elektriny neskôr zaviedol do jazyka fyziky kl’účový pojem pola, chápaného ako fundamentálna zložka fyzikálnej ontológie. A práve pojem pol’a figuruje na prvom mieste v obraze sveta súčasnej fyziky, ktorej sa chceme venovat' v nasledujúcej časti.

\section{Obraz sveta súčasnej fyziky}

Ako je známe, fundamentálna teória súčasnej fyziky nesie stručný názov štandardný model (ك̌M), alebo v rozvinutejšom tvare štandardný model fyziky elementárnych častíc a fundamentálnych interakcií. Vychádzajúc čisto z názvu by sme si mohli mysliet', že od Newtonových čias sa v princípe nič nezmenilo. Samozrejme, súčasná fyzikálna teória a experimentálna aparatúra dnešnej fyziky sú neporovnatel’ne zložitejšie a sofistikovanejšie. Keby sme však chceli pozerat' na všetky historické peripetie fyziky z vel'kého nadhl'adu, mohli by sme predsa len vnímat' ako upokojujúci fakt to, že 
stále ide v princípe o to isté, teda identifikovat' fundamentálne častice a príslušné fundamentálne sily, ktoré zabezpečujú interakcie medzi nimi. Obraz sveta, ktorý pred nami kreslí súčasná fyzika, je opät javiskom, na ktorom sú hlavné roly stále rozdané medzi dva typy fundamentálnych entít, častice a sily, a to, ako konkrétne dané entity „vyzerajú“, je už záležitost'ou jednotlivých čoraz lepších - obsiahlejších a exaktnejších - fyzikálnych teórií, do ktorých ako filozofi nemáme čo hovorit', pretože tie už patria do rúk profesionálnych fyzikov, teoretických a experimentálnych.

Hlavným zámerom tejto druhej časti textu je ukázat', že takého uvažovanie je prinajmenšom $\mathrm{v}$ jednom zásadnom bode chybné. Je chybou mysliet' si, že na utvorenie adekvátneho obrazu o ontológii súčasnej fyziky nám bude stačit' schéma časticovo-silového chápania sveta, nech už akokol'vek uvol’nená a zovšeobecnená. Presnejšie povedané, chceme tvrdit', že ak budeme vychádzat' z matematicky najprecíznejšie vypracovanej podoby súčasných fundamentálnych fyzikálnych teórií, mali by sme bud' radikálnym spôsobom zreformovat' svoje predstavy o ontologickom inventári sveta, alebo by sme si prinajmenšom mali začat' uvedomovat', že vyššie spomenutý upokojujúci pohl'ad na vec je hrubo zjednodušujúci. Mali by sme začat' byt' filozoficky znepokojení a udivení.

Aby bolo jasné, $\mathrm{k}$ akým zmenám v našom pohl'ade na svet vyzývame, pozrime sa bližšie na jednotlivé komponenty štandardného modelu, a to najprv tak, ako sa najčastejšie prezentujú pre širšie laické publikum: ŠM je teóriou viacerých typov elementárnych častíc a troch druhov fundamentálnych interakcií (síl). Máme šest' typov kvarkov (ktoré tvoria okrem iného protóny a neutróny), šest' typov takzvaných leptónov (medzi nimi elektrón a neutrína) a dvanást' typov bozónov (medzi nimi osem rôznych gluónov, jeden Z-bozón, dva W-bozóny a jeden Higgsov bozón). Tri fundamentálne sily sú: elektromagnetická, slabá a silná interakcia. Na „vysvetlenie“ toho, ako častice spolu interagujú, sa zvyčajne použiva záhadne znejúca formulácia, že sa tak deje tým, že častice si medzi sebou navzájom „,vymieňajú“ nejaké iné častice - napríklad dva elektróny, ktoré sa pri strete od seba „odrazia“ rôznymi smermi, si vymenili (virtuálne) fotóny.

Ak sa čitatel'ovi, ktorý nie je práve profesionálnym teoretickým fyzikom, javí takýto spôsob vyjadrovania málo zrozumitel'ný, ba dokonca trochu bizarný, nemožno mu to zazlievat'. Pre získanie prijatel'nejšieho obrazu o fyzike ŠM však neexistuje nijaká via regia, iba cesta podrobného štúdia základných matematických a experimentálnych aspektov tejto teórie. ${ }^{3}$ A práve štúdium týchto aspektov môže mat' za následok, že v našom myslení vzniknú zásadné zmeny, o ktorých sme hovorili o dva odseky vyššie.

${ }^{3}$ Našt’astie, v posledných rokoch sa objavilo viacero čitatel'sky ústretových učebníc, napríklad Klauber (2013); Lancaster, Blundell (2014); Edelhäuser, Knochel (2016); Schwichtenberg (2020). 
Adekvátny výklad konceptuálnych a matematických základov teórie štandardného modelu určite nemôže byt' realistickou ambíciou tohto článku, môžeme sa však napriek tomu pokúsit’ aspoň o letmý pohl’ad ,pod kapotu“, ktorý by nám umožnil priblížit' si filozofickú zaujímavost' súčasnej fundamentálne fyziky s ohl'adom na jej ontologickú problematickost'.

Teórie, ktoré tvoria ŠM, patria do širšej skupiny kvantových teórií pol’a (QFT). Presnejšie ide o takzvanú neabelovskú (lokálne) kalibračnú (kvantovú) teóriu pol’a. Táto teória vznikla dômyselným spojením troch koncepcií: klasickej teórie pol’a, špeciálnej teórie relativity a kvantovej mechaniky.

Kvantová teória pol’a ako konceptuálny rámec a matematický formalizmus štandardného modelu je založená na myšlienke, že fyzikálny opis sveta možno urobit' prostredníctvom kvantových polí, pričom všetko ostatné sa dá interpretovat' ako stavy a charakteristiky týchto fundamentálnych entít, respektíve ako výsledky interakcií niekol'kých základných typov kvantových polí. Častice, na ktoré sa ako na miniaturizované verzie každodenných predmetov rada upína naša predstavivost', sa v rámci QFT stávajú špecifickými („,časticovými“) stavmi kvantového pol’a. Ide o takzvané vzbudené (excitované) stavy pol’a, teda o tie stavy, ktoré sa nachádzajú na vyššej energetickej úrovni, ako je základná úroveň. Existencia diskrétnych energetických úrovní, teda fakt, že k zvyšovaniu energie polí nedochádza kontinuálne, ale v skokoch, po „kvantách energie“, vysvetl'uje pomenovanie kvantové (alebo kvantované) polia. Zároveň je to, samozrejme, most, ktorý kvantovú teóriu pol’a prepája s kvantovou mechanikou z dvadsiatych rokov dvadsiateho storočia.

Mnohí fyzici minulého storočia vnímali prechod ku kvantovej teórii pol'a ako fundamentálnemu aparátu fyziky ako najvýznamnejší úspech svojej disciplíny v druhej polovici dvadsiateho storočia. Tieto vysoké hodnotenia, prirodzene, vychádzajú najmä z riešení konkrétnych teoretických problémov, ktoré QFT priniesla (napríklad definitívne zosúladenie kvantovej teórie so špeciálnou relativitou), a z radosti nad ohromujúco presnými a úspešnými predikciami, ktoré poskytuje dlhé desat'ročia. V neposlednom rade však mnohých teoretických fyzikov teší tiež unifikujúci charakter QFT. Namiesto rôznych typov fyzikálnych entít, ako sú častice a sily, častice a vlny, častice a polia, QFT ponúka jednotný opis a jednotné vysvetlenie prostredníctvom ústredného pojmu kvantového pol’a. Zračí sa to aj v nasledujúcich výrokoch fyzikov, ako sú Weinberg, Schwinger, Mills, Wilczek, ktorí patria k hlavným spolutvorcoy ŠM: ${ }^{4}$

\footnotetext{
${ }^{4}$ J. Schwinger je spolutvorcom kvantovej elektrodynamiky (QED), R. Mills spolu s Ch.-N. Yangom zovšeobecnili matematický aparát QED na neabelovské kalibračné teórie, S. Weinberg sa podiel'al na tvorbe takzvanej elektroslabej teórie (zjednotenie teórie elektromagnetických a slabých interakcií),
} 
„Dve úplne nesúvisiace klasické koncepcie diskrétnych častíc a spojitých polí sú teraz zjednotené $\mathrm{v}$ tejto novej koncepcii kvantovaného pol'a - ba viac než zjednotené, - prekročené, pretože táto nová koncepcia obidve presahuje. (...) Kvantované pole bolo, z hl'adiska jeho historického vzniku, iba výhodným spôsobom ako sumarizovat' matematické vlastnosti nerozlíšitel'ných častíc, no čoskoro sa vd'aka čoraz väčšiemu rozvoju experimentálnej vedy stalo to, čo bolo chápané jednoducho ako matematická idealizácia, realitou (Schwinger 2001, 21 -22).

„Jediný spôsob, akým môžeme mat' konzistentnú relativistickú teóriu, je chápat' všetky častice prírody ako kvantá polí, ako v prípade fotónov" (Mills 1994, 386).

„Rovnice teórie pol'a, akou je štandardný model, nie sú o časticiach, ale o poliach; častice sa javia ako manifestácie týchto poli““ (Weinberg 1992, 25).

„V kvantovej teórii pol’a nie sú primárnymi prvkami reality individuálne častice, ale polia. Tak napr. všetky elektróny sú len excitáciami určitého pol’a, nazývaného elektrónové pole, ktoré vyplńa všetok priestor a čas“ (Wilczek 1999, 11).

Polia sa na prvý pohl’ad nejavia ako najvhodnejší kandidát na rolu fundamentálnych entít fyzikálneho univerza. Tým zaujímavejšia a naliehavejšia je z filozofického hladiska otázka, ako polia nadobudli - Schwingerovými slovami - tento nový status reality.

Z matematického hl'adiska sa pod „pol’om“ funkcia, ktorá prirad'uje každému bodu priestoru v danom čase určitú hodnotu: skalárnu, vektorovú či tenzorovú. Jednoduchým príkladom skalárneho pol'a je teplotné pole, čiže funkcia, ktorá v každom čase prirad’uje každému bodu (napríklad miestnosti) hodnotu teploty. Trochu zložitejšie je vektorové pole, ktoré v každom čase prirad’uje danému bodu nielen číselnú hodnotu (skalár), ale zároveň aj smer danej veličiny. Ako jednoduchý a názorný príklad môžeme $\mathrm{v}$ tomto prípade uviest' rýchlostné pole, charakterizujúce tečenie vody v koryte rieky: každý bod pohybujúcej sa masy vody si môžeme predstavit' ako zaopatrený šípkou, ktorej smer ukazuje, kadial' sa pohybuje infinitezimálny element vody v danom okamihu, a ktorej dížka predstavuje vel'kost' jeho okamžitej rýchlosti. Ako je zrejmé, poliam tohto druhu nie je potrebné ani rozumné pripisovat' samostatnú fyzikálnu realitu. Polia, ako je pole teplôt či pole rýchlostí, je najlepšie chápat' ako určitú formu matematickej reprezentácie daného fyzikálneho systému (masa vzduchu v miestnosti, pohybujúca sa masa vody v koryte rieky). To, čo existuje, sú molekuly vzduchu, respektíve molekuly vody, ktoré vykonávajú rôzne pohyby. Pole nie je dodatočná entita popri nich, ale je to len výhodná forma reprezentácie istých aspektov daných systémov.

F. Wilczek významne prispel k vzniku kvantovej chromodynamiky (QCD), teda teórie kvarkov a silných interakcií. Steven Weinberg je, mimochodom, aj autorom názvu štandardný model. 
Podobne možno v rámci klasickej fyziky chápat' aj reč o gravitačnom poli a gravitačnom potenciáli. No gravitačné pole by sme mohli interpretovat' aj ako novú fyzikálnu entitu (nielen čisto matematickú), ktorá vypíňa priestor v okolí hmotného telesa, alebo je určitou vlastnost'ou (modifikáciou) tohto priestoru. Analogicky by sme mohli v prvom momente uvažovat' aj o elektrickom a magnetickom poli v rámci klasickej teórie elektromagnetizmu, no tendencia pripísat' elektromagnetickému pol'u samostatnú realitu sa stala fyzikálne ovel'a relevantnejšou po objave elektromagnetických vín koncom 19. storočia. Napriek pokusom predrelativistických fyzikov (v konečnom dôsledku neúspešnom) interpretovat' toto vlnenie $\mathrm{v}$ rámci mechanistického modelu za pomoci určitého svetlonosného média (éter), vlny EM pol’a nesúce energiu a hybnost' priestorom nakoniec zostali niečím nenázorným, no zároveň z fyzikálneho hl'adiska vel'mi reálnym.

Klasický (nekvantový) elektromagnetizmus bol zároveň prvou verziou takzvanej kalibračnej teórie: namiesto elektrických a magnetických polí, ktoré vystupujú v Maxwellových rovniciach, túto teóriu možno matematicky preformulovat' $v$ potenciálovej podobe prostredníctvom takzvaného skalárneho a vektorového potenciálu (z matematického hl'adiska opät' polia), ktoré pripúšt’ajú rozmanité spôsoby matematického „nastavovania“ (kalibrácie) v závislosti od teoretických alebo prakticko-výpočtových potrieb (napríklad Coulombova kalibrácia, Lorenzova kalibrácia).

Tento princíp kalibrácie sa potom s ovel’a väčšou silou a ovel’a vážnejšími dôsledkami vracia v kvantovej teórii pol'a. Kvantová teória pol’a, na ktorej je postavený ŠM, je takisto kalibračnou teóriou, no okrem toho, že tento nový typ kalibrácie je z matematického hl'adiska výrazne komplikovanejší, má oproti teórii klasickej elektrodynamiky aj prekvapivé ontologické dôsledky. Ako sa ukazuje, nové polia, ktoré sú v tomto prípade matematicky generované uplatnením požiadavky (fyzikálnej) invariantnosti danej teórie vo vzt’ahu $\mathrm{k}$ istým typom matematických transformácií, ${ }^{5}$ možno chápat' ako úplne legitímnych členov rodiny polí, ktoré opisujú svet, pretože práve tieto kalibračné (bozónové) polia umožňujú nové vysvetlenie toho, čo sa označuje ako fundamentálne sily, respektíve fundamentálne interakcie.

Samozrejme, treba dodat', že každý súčasný fyzik pôsobiaci v tejto oblasti nie je pripravený vyvodzovat' z naznačených matematických konštrukcií závery o ontologickom inventári nášho univerza. Nakoniec, kvantová teória polí má aj v súčasnej podobe svoje problémy, ktoré sa doposial' nepodarilo odstránit' k všeobecnej spokojnosti. Nehovoriac už o tom, že aj po desiatkach rokov usilovného snaženia stále chýba

\footnotetext{
${ }^{5}$ Tieto transformácie sa dajú chápat' ako prvky určitých algebraických štruktúr nazývaných grupy, z ktorých niektoré majú a niektoré nemajú vlastnost' komutatívnosti. A ked’že komutatívne, respektíve nekomutatívne grupy sa synonymne označujú aj ako abelovské, respektíve neabelovské grupy, vo fyzike sa zvykne hovorit’ o abelovských a neabelovských kalibračných teóriách.
} 
úspešná verzia kvantovej teórie gravitácie, teda taká verzia Einsteinovej všeobecnej teórie relativity, ktorá by bola plne vybudovaná $\mathrm{v}$ konceptuálnom rámci kvantovej teórie pol'a. No odhliadnuc od všetkých nedostatkov tohto typu, ešte vždy zostáva otvorená jedna otázka, ktorá je filozoficky mimoriadne zaujímavá a ktorú sme postavili vo všeobecnej podobe na začiatku tohto článku: $\mathrm{V}$ akom zmysle a do akej miery možno interpretovat' abstraktné matematické objekty (napríklad spomínané kalibračné polia) nielen ako šikovné formálne nástroje na budovanie teórií a predikovanie výsledkov experimentov, ale aj ako náznak toho, že sa nám podarilo odhalit' nejakú hlbšiu vrstvu reality, nové fundamentálnejšie prvky fyzikálneho univerza?

Na takto položenú otázku dnes neexistuje nekontroverzná odpoved'. No pokial' sa nepodarí niekomu presvedčivým spôsobom preukázat', že sama formulácia takejto otázky nesplńa nároky sémantickej zmysluplnosti ( $\mathrm{k}$ čomu podl'a nášho presvedčenia zatial' nedošlo), otázka zostáva živá a predstavuje jeden z bodov prieniku medzi filozofickým a prírodovedeckým úsilím o porozumenie svetu.

Ako dôkaz toho, že problém realistickej, respektíve antirealistickej interpretácie matematického aparátu QFT je citlivým miestom aj v rámci fyzikálnej komunity, môže poslúžit' polemika odštartovaná článkom (Hobson 2013). Hobson je jednoznačným (a zrejme najhlasnejším) zástancom pol’ovej ontológie súčasnej fyziky. Väčšina fyzikov by síce súhlasila, že jeho argumenty proti časticovému chápaniu sú definitívne, mnohí však jedným dychom dodávajú, že kvantové polia reprezentované matematickými operátorovými pol’ami majú podobné problémy s prevzatím úlohy základných stavebných kameňov, ako sa to ukázalo pri časticiach. ${ }^{6}$ Spomedzi filozofov fyziky najvplyvnejšiu kritiku pol'ovej interpretácie QFT predložil David Baker, pričom jeho argumentačná stratégia takisto tkvie v poukázaní na to, ako t’ažkosti časticovej interpretácie sprostredkované dopadajú aj na tú pol’ovú (Baker, 2008). Baker však zároveň patrí do tej skupiny súčasných filozofov fyziky (T. Maudlin, M. Lange, S. French a i.), ktorí trvajú na tom, že nejaký ontologický obraz súčasnej fyziky je potrebný. Plne sa s nimi stotožňujeme v názore, že úhybný manéver do niektorej z radikálnejších verzií antirealizmu, respektíve inštrumentalizmu je neuspokojivý, pretože ten zväčša - okrem toho, že rezignuje na vysvetlenia - plodí iný typ problémov a konceptuálnych konfúzií.

Určitú minimalistickú verziu realizmu predstavujú varianty štrukturálneho realizmu, napríklad ontický štrukturálny realizmus S. Frencha. Túto cestu možno chápat' aj v duchu známeho Hertzovho výroku „Maxwellova teória je Maxwellova sústava rovníc“, ak pod tým rozumieme, že ontológiou je spoločný štrukturálny menovatel’, ktorý môže byt' reprezentovaný $\mathrm{v}$ rôznych reifikovaných podobách (vrátane časticovej a pol'ovej). Za hlavný deficit tohto návrhu považujeme to, že jadro ontologickej

\footnotetext{
${ }^{6} \mathrm{Ku}$ konkrétnym protiargumentom pozri septembrové číslo American Journal of Physics (2013).
} 
záhadnosti sa tu presúva na nie vel'mi presvedčivé rozlíšenie medzi matematickými a fyzikálnymi štruktúrami.

Je celkom možné, že primeraná odpoved' na tieto otázky bude musiet' zájst' hlbšie. V tomto smere je na zváženie napríklad Healeyho (opatrná) poznámka o tom, že sama „dekompozičná stratégia“ (ako označuje úsilie hl'adat' stavebné kamene prírody) možno pomaly dohráva svoju úlohu (Healey 2013, 56; 61). Samozrejme, kým sa dostatočne presne nepovie, čo je alternatíva, môže to vyzniet' ako iba d’alší rétorický trik. $^{7} \mathrm{~V}$ každom prípade je to prinajmenšom výzva pre filozofov, ktorí sa radi pohybujú $\mathrm{v}$ širšom mori konceptuálnych možností.

\section{Záver: retrospektíva a perspektíva}

Tradičné dejiny západnej filozofie začínajú pozoruhodnými pokusmi niekol'kých starogréckych myslitel'ov pochopit' svet ako kosmos, ktorého archai kai aitiai je možné odhalit' l'udským rozumom poučeným každodennou skúsenost’ou. Východiskom tohto textu je presvedčenie, že otázky, ktoré sa týkajú povahy sveta ako celku, jeho fundamentálnych elementov a zákonitostí, stále sú a mali by aj zostat' súčast'ou filozofie ako akademickej disciplíny. Tento postoj so sebou, samozrejme, nevyhnutne nesie otázku, aká je úloha filozofie v procese poznávania fundamentálnych štruktúr a prvkov univerza, a táto otázka je naliehavejšia o to väčšmi, že v rámci súčasných prírodných vied - špeciálne vo fyzike vysokých energií a v kozmológii - si tieto otázky, ako sa zdá, našli svoj prirodzený domov.

Ak tento typ pýtania sa prijmeme ako legitímnu súčast' filozofie, máme v zásade tri možné spôsoby ako postupovat': metafyzický, fenomenologický a naturalistický. Metafyzická cesta predstavuje pokus rozvíjat' autonómnu filozofiu prírody, nezávisle od postupov a výdobytkov empirických vied, pričom ambíciou je objavit' ešte hlbšiu jednotu a ešte fundamentálnejšie prvky prírody, než je toho schopná prírodná veda. Pod fenomenologickým prístupom tu rozumieme taktiež istý druh autonómneho hl'adania základných elementov, no v tomto prípade nejde o tromfnutie vedy v jej úsilí, ale o prevrátenie optiky: základné elementy prezentované vo vedeckých teóriách sú interpretované ako abstraktné konštrukty, ktoré slúžia istým obmedzeným cielom, a za skutočné základné entity sa vyhlasuje to, čo je bezprostredne evidentné a vnímatel'né, veci nášho prirodzeného sveta (Lebenswelt). Naturalistický prístup prichádza oproti obom predchádzajúcim - $\mathrm{s}$ výrazným obmedzením autonómie filozofie vo veci hladania adekvátnej ontológie prírody. Jeho ústredným mottom je aj na tomto poli hlboká quineovská nedôvera k ,,prvej filozofii““. Úlohou filozofa je podiel’at’ sa svojím

\footnotetext{
${ }^{7}$ Dodajme, že toto nie je kritika Healeyho, ale skôr priznanie, že v rámci tohto textu už nemôžeme podat' podrobnejší výklad. Richard Healey je autorom jednej z filozoficky najlepších a matematicky najerudovanejších prác, venovaných práve interpretácii súčasných kalibračných teórií (Healey, 2007).
} 
kúskom na celkovom procese poznávania a prispievat' bez toho, že by si nárokoval kompetencie teoretických a experimentálnych prírodných vied. Jeho part však nemusí byt' bezvýznamný, pokial' ho dokáže hrat' so znalost'ou problematiky, historickou akríbiou a s pojmovou precíznost'ou.

Za optimálnu stratégiu vo filozofii vedy vo všeobecnosti pokladáme práve takto chápaný naturalistický postoj. Toto prihlásenie k naturalizmu si však žiada niekol'ko dodatočných poznámok. Naturalizmus (v našom ponímaní) nemôže byt' - takpovediac zo svojej podstaty - dogmatický v tom zmysle slova, že si osvojuje a za každú cenu presadzuje jednu verziu (fundamentálnej) vedeckej teórie. Naturalistický prístup chápeme ako filozofický postoj k spôsobom skúmania sveta, nie ako propagáciu alebo apológiu momentálne dominujúcej fundamentálnej teórie. Filozofia (fyziky) má byt' ponorená v prostredí vedeckého skúmania, ale nemá sa $\mathrm{v}$ ňom (nechat') utopit'. Naturalistický filozof v ňom musí vediet' plávat', aj ked’ štýlom odlišným od (nefilozofujúceho) vedca.

Napriek tomu, že vymedzili naturalizmus v kontraste k metafyzickému a fenomenologickému prístupu, pokladáme za dôležité primerane zohl'adňovat' niektoré ich aspekty. Po prvé, naturalistická filozofia fyziky by pre silnú naviazanost' na aktuálne najúspešnejšie fyzikálne teórie nemala strácat' $\mathrm{z}$ dohl'adu fenomenologický problém prepojenia medzi „zjavným“ a vedeckým obrazom sveta (v Sellarsovom zmysle). A to aj preto, že sémantika aj tých najabstraktnejších teoretických koncepcií na začiatku vzišla a v konečnom dôsledku je prístupná práve z našej (relatívnej a podmienenej) skúsenosti s javmi, ktoré sa nás doslova dotýkajú. Zveličenie alebo dokonca absolutizovanie tejto podmienenosti môže viest' $k$ subjektivizmu - ale iba tejto hypertrofii by sa mal naturalista vystríhat'. A po druhé, metafyzický impulz v zmysle revizionistickej metafyziky môže byt' tiež čiastočne užitočne kooptovaný do naturalistického spôsobu práce, pretože schopnost' pozriet' sa radikálne inak aj na zabehané a osvedčené metódy a schémy myslenia je klúčová pre samo vedecké skúmanie.

Čo to znamená konkrétne vo vzt’ahu k fundamentálnej fyzike súčasnosti vo forme kvantovej teórie pol’a a jej novej sugestívnej a unifikujúcej ontológii? Znamená to, $\mathrm{z}$ nášho pohl'adu, pracovat' $\mathrm{v}$ rámci naturalistickej perspektívy (okrem už spomenutého) na troch typoch úloh: 1 . poskytovat' širšie intelektuálne historické pozadie pre súčasné fundamentálne fyzikálne teórie, ${ }^{8} 2$. podiel'at' sa na pojmovom rozpletaní a vyjasňovaní rozdielov medzi metaforickými (analogickými) a doslovnými spôsobmi hovorenia v súvislosti s prezentáciami fyzikálneho obrazu sveta, ale aj v súvislosti s každodennou prácou fyzikov, v ktorej môže byt' toto prelínanie heuristicky mimoriadne

${ }^{8}$ Jedným zo vzorových príkladov takýchto filozoficky motivovaných a filozoficky prínosných historických diel sú práce Mary Hesse - v súvislosti s témou tohto článku je osobitne zaujímavá jej kniha (Hesse 1962). 
užitočné, 3. kritickou pojmovou analýzou strážit' a ošetrovat' tie miesta fyzikálneho slovníka, kde často dochádza k (na pohl'ad možno nevinným) nejasnostiam a ambivalenciám, no so sklonom k nebezpečným kategoriálnym omylom. ${ }^{9}$

A na úplný záver: Ako stručne odpovedáme na štyri otázky, ktorými sme tento článok začali?

- Súčasné fundamentálne fyzikálne teórie skôr vylučujú mnohé oblúbené obrazy sveta, než by nám nejaký presvedčivý poskytovali / sugerovali (odhliadnuc od ad hoc heuristických výhod toho-ktorého modelu).

- Očakávat' obraz v zmysle niečoho názorného alebo vizualizovatel'ného by bolo naivné, no pýtat' sa na ontológiu fyziky je stále opodstatnené.

- Ak na chvíl'u zavrieme oči pred „drobnými“ technickými problémami, potom je v súčasnosti najlepšou vol'bou chápat' ako základné entity kvantové polia.

- Miera dôvery závisí od konkrétnej zvolenej interpretácie matematického aparátu, ale vo všeobecnosti máme dôvody byt' skôr opatrní ako triumfalistickí. ${ }^{10}$

\section{Literatúra}

BAKER, D. J. (2009): Against Field Interpretations of Quantum Field Theory. British Journal for the Philosophy of Science 60, 585 - 609. DOI: https://doi.org/10.1093/bjps/axp027

COHEN, I. B. (1971): Introduction to Newton's „Principia“. Cambridge: University Press.

EDELHÄUSER, L, KNOCHEL, A. (2016): Tutorium Quantenfeldtheorie. Berlin: Springer.

FRENCH, S. (2014): The Structure of the World. Oxford: Oxford University Press.

HALL, A. R., HALL, M. B. (1962): Unpublished Scientific Papers of Isaac Newton. London: Cambridge University Press.

HEALEY, R. (2007): Gauging What's Real. Oxford: Oxford University Press.

HEALEY, R. (2013): Physical Composition. Studies in History and Philosophy of Modern Physics 44, 48 - 62. DOI: https://doi:10.1016/j.shpsb.2011.05.001

HESSE, M. B. (1962): Forces and Fields. The Concept of Action at a Distance in the History of Physics. New York: Dover Publications, Inc.

HOBSON, A. (2013): There are no particles, there are only fields. American Journal of Physics, 81 (3), 211 - 223. DOI: https://doi.org/10.1119/1.4789885

JANIAK, A. (ed.) (2004): Isaac Newton: Philosophical Writings. Cambridge: Cambridge University Press.

KLAUBER, R. D. (2013): Student Friendly Quantum Field Theory. Fairfield: Sandtrove Press.

LANCASTER, T., BLUNDELL, S. J. (2014): Quantum Field Theory for the Gifted Amateur. Oxford: Oxford University Press.

MILLS, R. (1994): Space, Time and Quanta. New York: W. H. Freeman and Company.

\footnotetext{
${ }^{9}$ V kontexte tohto článku máme na mysli napríklad konfúzne nerozlíšené používanie termínu pole jednak v matematickom zmysle, a jednak vo fyzikálnom zmysle, čo síce v niektorých prípadov môže predstavovat' len pragmatickú skratku v prúde hovorenia (či písania), no v iných prípadoch môže viest' prinajmenšom $\mathrm{k}$ zbytočným zavádzaniam, $\mathrm{v}$ horších prípadoch $\mathrm{k}$ bizarným ontologickým koncepciám napríklad takého typu, ako je práca M. Tegmarka Our Mathematical Universe (2014).

${ }^{10} \mathrm{Za}$ dobre cielené pripomienky d’akujem anonymnému recenzentovi. Štruktúra a rozsah článku, bohužial', neumožnili ich plné zohl'adnenie a zapracovanie.
} 
NEWTON, I. (1687): Philosophiae naturalis principia mathematica. London: Royal Society.

NEWTON, I. (1721): Opticks, or a Treatise of the Reflections, Refractions, Inflections and Colours of Light. London. The Third Edition.

SCHWICHTENBERG, J. (2020): No-Nonsense Quantum Field Theory. Karlsruhe: No-Nonsense Books.

SCHWINGER, J. (2001): Quantum mechanics: Symbolism of Atomic Measurements. Berlin: Springer. WEINBERG, S. (1992): Dreams of a Final Theory. New York: Random House, Inc.

WILCZEK, F. (1999): Mass without Mass I. Most of Matter. Physics Today, 52, 11, 11 - 13. DOI: https://doi.org/10.1063/1.882879

Článok vznikol ako súčast' riešenia grantového projektu VEGA, Realizmus a antirealizmus v súčasnej filozofii vedy, č. 1/0258/2019.

Róbert Maco

Univerzita Komenského v Bratislave

Filozofická fakulta

Katedra filozofie a dejín filozofie

Gondova 2

81102 Bratislava 1

Slovenská republika

e-mail: robert.maco@uniba.sk

ORCID ID: https://orcid.org/0000-0001-5061-9344 